\title{
PATOČKA'S CRITIQUE OF HUSSERL: The Possibility of A-Subjective Phenomenology ${ }^{1}$
}

GABRIEL VIDAL

Dhenomenology embodies the project of founding a new philosophical departure, one detached, if possible, from the mistakes—and especially of the biases—of former traditions and serves as a proper philosophical foundation. ${ }^{2}$ The founder of this tradition, Edmund Husserl, proposes breaking with the subjective excesses of idealism and the naïve schemes of realism. This implies the task of debunking two theses: on one hand, the idea that the subject is the creator of the objects that appear to him and, on the other, the idea of the absolute independence of objects, or the thesis of the thing in itself. ${ }^{3}$ The path taken by Husserl in order to debunk both theses aims to restore the connection between the two dimensions at stake-subjectivity, and objectivity—by putting at the forefront their correlation. To do this, we must abstain ourselves from anticipating any unproven thesis in our investigation and exclusively refer back to the description of appearances in themselves. This is because everything that has the slight possibility of entering into our consideration does so

1 This article contains quotes that are originally in Spanish. All translations have been made by me in this case.

2 David Woodruff Smith, "Phenomenology," in The Stanford Encyclopedia of Philosophy, ed. Edward N. Zalta, Summer 2018 (Metaphysics Research Lab, Stanford University, 2018), https://plato.stanford.edu/archives/ sum2018/entries/phenomenology/.

3 This mainly refers to Kant's Thesis as outlined in Critique of pure reason Immanuel Kant, Critique of Pure Reason, ed. Paul Guyer and Allen W. Wood (Cambridge: Cambridge University Press, 1999). However, It does not only refer to Kant's interpretation, but to whatever doctrine that considers the object as completely independent of a subject's knowledge or experience. 
insofar as it appears, and thus only the ways things appear will bring light to the mentioned correlation. Phenomenology asks us to attend exclusively to what is given in our description of it. Staying in this dimension of primitive donation ${ }^{4}$ of content is what gives phenomenology its rigor, to which Husserl remains faithful in the creation of this new science.

Nonetheless, many posterior phenomenologists have criticized Husserl for overemphasizing one of the two poles of the correlation - namely, the subjectiveand so accusations of subjectivism became commonplace in transcendental phenomenology. ${ }^{5}$ The appearance seems to be constantly described in terms of a donation towards and made by the consciousness of a subject, and the acts by which the subject point to objects, but not the other way around. ${ }^{6}$ The problem is that most of the successors have simply disregarded Husserl's point of view, and have restarted the task from mostly different considerations without taking into account his foundational concerns. Jan Patočka is one of the few authors who has revised the foundational problem of phenomenology from a properly Husserlian approach to mind.

If we agree on the fact that Husserl was successful in setting the foundations of phenomenology, then we could claim that, if those foundations are incorrect, then further developments of phenomenology are completely misguided. However, if we can correct Husserlian phenomenology from its mistakes while keeping the foundation unaffected, then we can be reassured of phenomenology's future. This is why the possibility of phenomenology itself may be at stake under Patočka's criticism. If phenomenology, since its inception, already carried a bias in favor of subjectivism, then it was doomed to be a failed attempt at a new departure from former tradition. Patočka's intention is, indeed, to correct this misguided inclination towards subjectivism in Husserl's account, while keeping the fundamental features of phenomenology that allow us to recognize it as unaffected.

I will proceed in showing the most important elements of Husserl's phenomenology: constitution, epoché and reduction, the Husserlian description of perception, and the noesis/noema scheme. Then, I will show Patočka's attacks to the previously mentioned points and how these critiques reveal a subjectivist tendency in Husserl, specifically in the gesture of reduction. Finally, I will demonstrate Patočka's proposal of an a-subjective phenomenology that dispenses with reduction and explores a world-horizon as the a priori background of appearances.

4 The original word is "donación". It means something like "to be given as it is". When a content is given to consciousness, or makes its presence into it, that's a donation or (donación).

5 Robert J. Dostal, "Subjectivism, Philosophical Reflection and the Husserlian Phenomenological Account of Time," in Phenomenology on Kant, German Idealism, Hermeneutics and Logic: Philosphical Essays in Honor of Thomas M. Seebohm, ed. O. K. Wiegand et al. (Dordrecht: Springer Netherlands, 2000), 53, https://doi. org/10.1007/978-94-015-9446-2_4.

6 George Alfred Schrader, "Philosophy and Reflection: Beyond Phenomenology," The Review of Metaphysics 15, no. 1 (1961): 92. 


\section{Husserl's Phenomenology}

The necessity of showing the correlation is first seen in Logical Investigations, ${ }^{7}$ where Husserl engages in a critique of psychologism, which he claims reduces the logical dimension to that of empirical psychology, and completely disregards its apodictic and ideal character. ${ }^{8}$ In order to elucidate this issue, Husserl traces a distinction between the acts, which allows thoughts about content, and the contents themselves, whereas psychologism reduces all logic only to the acts. ${ }^{9}$ In this way, he shows that the same content can be conceived of, by employing completely different acts of thought (for example, the number " 5 " can be given to consciousness from conceiving five points as well as five lines). This demonstrates that in order to elucidate the issue of both the ideality and empirical reality of math and logic, it is necessary to pay attention to the correlation of contents and acts in a completely unbiased way, without advancing any thesis about it. Therefore, the inquiry will be about how it is possible that these ideal entities appear in consciousness, or how the apodictic can make its way "inside" something that is singular and contingent. The issue is solved when it is realized that, although ideal entities make their way into consciousness by means of acts, "the subject cannot constitute whatever signification, so constituent acts depend on the essence of the objects in consideration." 10

Here, the concept of constitution is discovered. That is, contents appear; they are not constructed, but are rather brought into presence. Constituent acts are "what makes the object representable" and "do not entail anything else but the act of going out to encounter the entity, in such a way that this entity, in the same act by which it is encountered, can announce itself." ${ }^{11}$

This way of conceiving the donation of objects makes Husserl think of consciousness differently. Consciousness is always a consciousness of something, such that the content of its consideration always accompanies it. ${ }^{12}$ It is not a closed-in-itself structure that is then filled with contents, but it is in itself the pointing towards the object. That activity defines consciousness' essence. This is pure direction of consciousness towards the object — or intentionality — is the only thing that we can properly affirm about consciousness. ${ }^{13}$ This allows Husserl to affirm that constitution does not equal the construction of the object: the act is not, in some way, the absorption of the object inside a closed in consciousness, but is rather the appearance of the object to

7 Edmund Husserl, Logical Investigations (Routledge, 2013).

8 Dan Zahavi, Husserl's Phenomenology (Stanford University Press, 2003), 8-9.

9 Robert Hanna, "Husserl's Arguments against Logical Psychologism," Edmund Husserl: Logische Untersuchungen, 2008, 78.

10 Walter Biemel, "Las Fases Decisivas En El Desarrollo de La Filosofía de Husserl," in Husserl. Tercer Coloquio Filosófico de Royaumont (Buenos Aires: Paidós, 1968), 46.

11 Ibid., 47.

12 Carlo Ierna, "Making the Humanities Scientific: Brentano's Project of Philosophy as Science," in The Making of the Humanities. Volume III: The Making of the Modern Humanities, ed. Rens Bod, Jaap Maat, and Thijs Weststeijn (Amsterdam University Press, 2014), 547.

13 A. David Smith, "Husserl and Externalism," Synthese 160, no. 3 (2008): 319-20. 
an intentional consciousness (the object is pointed by intentionality and makes its presence).

I have said that in order to describe 'appearance as such,' one must attend to what is given, refraining from fabricating conjectures outside that pure donation. This motivates Husserl, in Ideas $I,{ }^{14}$ to pin down what this refraining attitude consists in. He calls this the epoché, and by means of this epoché, we can:

Put out of action the general thesis which belongs to the essence of the natural standpoint, we place in brackets whatever it includes respecting the nature of Being: this entire natural world therefore which is continuously 'there for us', 'present to our hand', and will ever remain there, is a 'factworld' of which we continue to be conscious, even though it pleases us to put it in brackets. ${ }^{15}$

This does not imply the denial of the existence of the world, but implies, rather, its independence as a reality in itself. In this case, it would be possible for the world to be independent of any constituent act. Denying this thesis, then, allows one to make the world appear to an intentional consciousness instead of speculating about it without evidence. What appears to the intentional consciousness constitutes evidence, ${ }^{16}$ and what does not appear to it is just subjective construction. So, one can see that the epoché not only implies a suspension of the thesis of the independence of the world, but that it also implies a reduction to the intentional field of consciousness. ${ }^{17}$ In fact, everything that appears into our consideration does so insofar as it is assessed by this intentional field, which the epoché only takes out of its anonymity. By being faithful to this epoché, we do not make conjectures about what appears; we only describe what appears before the intentional field through constituent acts. If anything is to possess phenomenological validity, then a constituent act is required. This is what commitment to the epoché means: being faithful to the phenomenological reduction by always asking for the constituent act of the object in question. ${ }^{18}$

Later in his endeavor, Husserl again describes perception under the new concepts reviewed in the section above. After we commit to epoché, we develop a consciousness that points to objects in a completely equal correlation, where the object is neither created by the subject nor exists in a partial transcendence. Therefore, now the description of perception, reduced to the intentional field of consciousness, no longer risks becoming either subjectivism or realism. Therefore, perception will be constituted by three stages: hyletic, noetic and noematic. The hyletical stage refers to hyle as the basic matter of perception; namely, the pure sensation that makes no

14 Edmund Husserl, Ideas: General Introduction to Pure Phenomenology (Routledge, 2014).

15 Ibid., 110.

16 Ülker Öktem, “Husserl's Evidence Problem," Indo-Pacific Journal of Phenomenology 9, no. 1 (May 1, 2009): 3, https://doi.org/10.1080/20797222.2009.11433986.

17 Steven Crowell, "Phenomenological Immanence, Normativity, and Semantic Externalism," Synthese 160, no. 3 (2008): 339.

18 Husserl, Ideas, 364. 
reference to any object whatsoever, in the purely experienced sensation. ${ }^{19}$ In this sense, it consists of a cogitatio that is a mere ingredient of consciousness, where the ingredient is what makes the private current ${ }^{20}$ of the subject's experiences. This purely immanent hylé is later animated by noesis, which is the stage in which the purely experienced becomes a trait of a thing. ${ }^{21}$ For example, the pure green becomes the green of a leaf. In this stage hylé no longer makes reference to itself, but instead points towards an object. In this stage, intentionality starts operating and allows consciousness to get outside of itself. Finally, noesis allows the noema to enter, which is the pointed object donated by an intuition. ${ }^{22}$ In the noetical moment, we point to the object, which by means of intuition, then allows the object to make itself present in the noematical stage. We can even describe falsity and truth within this schema: I can point noetically towards something that does not present itself noematically. In other words, I prepend a signification that does not correspond to the given intuition. Only when the signification is filled with a corresponding intuition does the constitution of the object become successful. ${ }^{23}$

Although the former description underlies an effort to attribute equal importance to the subject and object roles respectively, it probably seems that the object is given only by means of acts of consciousness. Thus, it becomes dubious if things that appear to the subject are transcendent to it. There is a chance that everything will be components of consciousness. Husserl solves the issue by introducing the concept of foreshortening. ${ }^{24}$ There's a substantial difference between merely immanent experiences and proper perceptions. Immanent experiences are given in a completely adequate way to the subject; they are conceived in a completely transparent way. ${ }^{25}$ In other words, the thing is immediately and completely ended in all its possibilities of being perceived by the subject. Perceptions, on the other hand, are always only shown partially; one can never end all the possible perspectives that the object has to offer. ${ }^{26}$ This means that perceptions are given inadequately. This foreshortened way of being brought into presence guarantees its exteriority since "an experience is only possible as a living experience but not as anything spatial." ${ }^{27}$

19 Patrick Whitehead, "Phenomenology Without Correlationism: Husserl's Hyletic Material," Indo-Pacific Journal of Phenomenology 15, no. 2 (October 26, 2015): 6, https://doi.org/10.1080/20797222.2015.1101830.

20 By 'private current' I mean the subject's own flow of consciousness that is available only to himself. His thoughts, emotions, mental images and other things in motion constitute this private current.

21 Kenneth Williford, "Husserl's Hyletic Data and Phenomenal Consciousness," Phenomenology and the Cognitive Sciences 12, no. 3 (September 1, 2013): 502, https://doi.org/10.1007/s11097-013-9297-z.

22 Ibid.

23 Lambert Zuidervaart, "Synthetic Evidence and Objective Identity: The Contemporary Significance of Early Husserl's Conception of Truth," European Journal of Philosophy 26, no. 1 (2018): 125, https://doi.org/10.1111/ ejop.12192.

24 The original term for this mode of appearance is Abschattung, and it refers to things that are given as not showing all of its sides. The reference painting tries to portray the idea of an unfinished sketch or perspective. Renaud Barbaras, Introducción a una fenomenología de la vida: intencionalidad y deseo (Encuentro, 2013), 43.

25 Juha Himanka, "Husserl's Two Truths: Adequate and Apodictic Evidence," Phänomenologische Forschungen, 2005, 93.

26 María Paredes, "Percepción y Atención. Una Aproximación Fenomenológica," Azafea: Revista de Filosofia; Vol. 14 (2012), 2014, 84-85, http://revistas.usal.es/index.php/0213-3563/article/view/11680.

27 Husserl, Ideas, 41. 
Here, the distinction between acts and contents is raised again: even though the thing is given through multiple and different foreshortenings, it nevertheless points towards a unique object. Perception is already accompanied by the realization that the perspectives refer to the same object. We do not need to complete all the possible perspectives, nor do we need the mediation of a secondary abstraction or to provide a metaphysical explanation for this realization. In other words, the unity of the object is already given in perception by the many perspectives. This is called apprehension unity. ${ }^{28}$ Both the possibility of the unity of the object and the foreshortened exteriority guarantee that things are not created by the subject. However, this is not a completely transcendent transcendence ${ }^{29}$ in the sense that does not imply the independent existence of a world, but, rather, it implies exteriority for the intentional consciousness. In this sense, the external constitutes a transcendence inside immanence, ${ }^{30}$ which is verified thanks to unprejudiced scrutiny of appearance that, therefore, it is inclined neither towards the subjectivist idealist thesis nor the realism of things in themselves.

\section{Patočka's Critique}

We must emphasize that, for Husserl, in the act of perception, only experiences are components of consciousness. Perception as such, however, including the foreshortenings and apprehension of unity, has an objective character. This betrays, according to Patočka, the explanation that Husserl himself proposed as a distinction for experiences and perception. Husserl says that the foreshortened donation of things guarantees the external character, and, so, everything that is given adequately constitutes consciousness' components. Indeed, foreshortenings are given to the subject as empirical data, which lacks signification. But in the case of what is also supposed to be given as objective — namely the apprehension of unity-the donation is neither forefronted nor empirical data, "but apprehension itself is affirmed; it is not any affluence of new sensations, but it has the character of an act, a mode of consciousness or a state of the spirit." ${ }^{31}$ Since apprehension itself does not correspond to any proper intuition and is nothing empirical, one must conclude that constitutes signification itself. As such, it has the character of being an act of the subject and appears with the same apodictic evidence that is characteristic of the subjective experience. Therefore, apprehension taken as such corresponds to an adequate

28 Smith, "Husserl and Externalism" 326.

29 By 'transcendent transcendence,' I mean that the objectivity or externality of the thing has to resort to something that is beyond (or outside of) consciousness. This is why it is a 'transcendent transcendence', and is directly opposed to 'immanent transcendence' (a Husserlian notion), which assures the externality of the thing without resorting to something beyond consciousness.

30 Dermot Moran, "Immanence, Self-Experience, and Transcendence in Edmund Husserl, Edith Stein, and Karl Jaspers," American Catholic Philosophical Quarterly, May 1, 2008, 268, https://doi.org/10.5840/ acpq20088224.

31 Jan Patočka, El movimiento de la existencia humana (Encuentro, 2004), 103. 
experience (not a foreshortened one) so that there is nothing indicating its external or objective character:

To summarize: sensations and the acts that apprehend them or perceive them are lived, but they do not appear objectively; they are not seen, heard or perceived with any «sensory faculty». We have before our eyes Husserl's subjectivism in germinal state. ${ }^{32}$

These critiques demystify the supposedly objective character of apprehension of unity and, therefore, it loses its status as a perception, since apprehension is not an intuition of anything, but an act of signification, void of any empirical content. In light of this, apprehension enters the field of what constitutes consciousness, assuming we are faithful to Husserl's own explanation:

Subjective being does not foreshorten, it merely shows itself as what it is. Therefore, in the first place, the phenomenical sphere is divided into two stages: what appears in its modes of being given, on one hand, and the supposed subjective basis of this appearance, on the other hand. ${ }^{33}$

In his project, Husserl restarts the former conception of consciousness, which is characterized by considering the subjective modes of being as intramental and the objective as extramental-or, in Husserlian terms, what is component and what is spatiotemporal. Though Patočka doesn't explicitly elucidate how this critique affects the noema/noesis schema, it can be easily understood. Noesis as such is not empirical; it is an animation of data that imbues noema/noesis with the capacity to have a direction towards an object. Due to this lack of empirical data-and the possibility of being foreshortened-one concludes that noesis is an adequate experience, a component. Noesis, thus, takes the side of the subjective (and noema of the objective), and the appearing process splits in two again. Finally, this confusion irradiates to hyletical data, since one cannot determine if they are components or foreshortenings. There are two equally probable answers: hyletical data are either foreshortened perspectives that acquire signification thanks to noesis, or they are components of consciousness that become externally directed thanks to noesis.

The aforementioned misunderstandings and contradictions rest, however, in a more fundamental mistake, according to Patočka. The great achievement of Husserl is, indeed, the discovery of the "phenomenological field" and the birth of describing the appearance as such in that field, but:

It is true here that Husserl has not abandoned the fundamental idea of a general correlation between appearances and what appears, he has even reinforced and elevated the entire philosophical endeavor to the methodical. However, a curious combination of Cartesian and Kantian ideas alongside the original idea of an intuitive foundation of knowledge

32 Ibid.

33 Ibid., 105. 
that transcends argumentation lead here to the idea of a phenomenological reduction to the pure immanence of consciousness. ${ }^{34}$

Indeed, Husserl tries to attend to appearances as such and to correlation, but when he tries to constitute this knowledge as a rigorous science, "he attempts, in a curious analogy with the cartesian concern with doubt, to methodically highlight and secure this dimension." 35

The procedure chosen to do this, for Descartes, implies remitting to the apodictic dimension of the subject. In other words, the reduction to pure immanence is fundamentally an alternative term for the subjective, since it relies on an equal correlation of subject and object, and is thereby accompanied by the additional claim because it is an intentional field. But as was aforementioned, claiming its intentional nature does not solve the problem - the correlation of subject and object is always marked by the objectifying acts of the subject. This means that intentionality is only directed from the subject to the object, but not vice versa. All things considered, we find that the classical bifurcation of the world is accidentally replicated, now in the distinction between what is component and what is spatiotemporal. This is a dichotomy that intentionality alone cannot dissolve-it merely transports it.

One could say that in order the prevent the claim of an in-itself world, Husserl constantly refers to the appearance of the former only for a consciousness, but this has resulted in reducing appearances to the subjective experience, without considering the possibility that admitting that the autonomy of the phenomenical field is not equivalent to restarting the thesis of the thing in itself. The merely methodological commitment of evading the thing in itself started to slip into more serious claims of subjectivism.

Husserl, in fact, tries to describe appearances as such, and is aware that in order to describe the universal a priori of correlation, it is not possible to reduce appearances as such to any of the entities that appear in this field. That would imply the absurd claim that the appearance itself depends on the things that this field produces. However, in order to evade the thesis of the thing in itself, Husserl relies excessively on the dimension of immanent consciousness, in which he finds that there is complete and indubitable evidence. So he ends up relying completely on the self:

The intention points, therefore, to appearances as such, to the phenomenical sphere. But this intent is sketched in terms that come from the sphere of the subjective: he tries to speak about a reduction to pure immanence instead of putting on display the field of appearances as such. ${ }^{36}$

Even though its initial motivation is always to stay true to the correlation, objectivity ends up being defined as "something that appears in living and is transcendent to 
the ingredient stream of experiences." ${ }^{37}$ In this way, the constitution of thingswhich claims to debunk that objects are created by consciousness or that things in themselves exist independently - is impossible if we do it from the presupposition that everything is put under the assessment of the immanence of intentional consciousness. It can be said, then, that this "transcendence inside immanence" fails:

Ultimately, the whole problem of constitution is irresolvable. How can 'living as such', as it is originally given in reflection, start to make something an objective, transcendent appearance? One cannot have intellectual evidence about it - it can only be accepted as a brute fact. Nothing should be questioned about it if it were not, in fact, an ultimately intuitable fact, but rather, an authentic fact, and not a construction. ${ }^{38}$

Indeed, Husserl's conjecture that the psychic is internal comes, according to Patočka, from Brentano's interpretation of Cartesianism:

If the intentional object is not immanent but precisely transcendent to the subject, and the Brentanian apprehension of the psychic as an internal object remains, then it follows, necessarily, that the fundamental distinction is between lived experience and phenomena. Living experience does not appear, but is already there as a component that flows through time and causes the appearance of things. By virtue of living experiences transcendences appear. ${ }^{39}$

This means that the subjective (psychic) is not one of the many kinds of entities that appear by means of the appearance as such, but, rather, is a privileged dimension that is the cause of the appearance in general. By this mistake, the procedure of epoché is also misunderstood because it is presupposed that epoché implies a "reduction" to the immanence of the subject. This is based on the misguided belief that if consciousness is intentional, then it is no longer closed in itself because is only direction towards the object. However, this is not possible if the psychic/internal mode of conceiving it is not abandoned. If not abandoned, the transcendent and immanent restart the intramental/extramental distinction that it purports to overcome. ${ }^{40}$

\section{Patočka's proposal}

From the critique previously sketched, it is clear that the main attack resides in the understanding of the investigation of appearance as reduced to the immanence of consciousness. This produces all the problems that, in the end, are attributed to subjectivism. However, it is true that the investigation of appearances requires a

37 Ibid., 107.

38 Ibid., 108.

39 Ibid., 124.

40 Husserl pretended to demonstrate that sources of knowledge for phenomenology were not internal nor external Biagio G. Tassone, "The Relevance of Husserl's Phenomenological Exploration of Interiority to Contemporary Epistemology," Palgrave Communications 3 (July 11, 2017): 8. 
disconnect from any possible thesis about the world ${ }^{41}$ and must remain faithful only to describing appearance as such:

[...] Phenomenology itself should be a science: an a priori science of the essential legalities that govern the appearance process of what appears as such [...] it is not an argumentative basis that resorts to the self as the ultimate explicative concept, but a revealing foundation that legitimizes the idea of foundation as such. ${ }^{42}$

If phenomenology is supposed to be given the task of describing appearances as such, then this appearance cannot be based on one of the entities that appear, since that would require what is needed for explanation to reside within the explanation. From this point of view, both the subjective and the objective are things that made its presence in the phenomenological field as any other. This phenomenical field is, therefore, autonomous, ${ }^{43}$ it is the condition of possibility for the apparition of every entity, but this field itself is no entity. Husserl's mistake is reducing it to one of the entities that appear:

There is a phenomenological field, a phenomenological being itself, which cannot be reduced to any entity that appears within it. Therefore, it can never be explained by the entity, even if this is objective, as in nature, or subjective, as in the self. ${ }^{44}$

It follows that in order to describe appearances as such without biases, one must abstain from positing any thesis that we had with respect to appearance. That is precisely the role of the epoché, which "[...] claims that a thesis is neither attempted nor purported, but that one only experiences the freedom to use it or not to use it." ${ }^{45}$ It does not follow, however, from this abstention, that one should commit to a "reduction"; this requirement is added by Husserl in order to bring himself back to an indubitable sphere. In this sense, the reduction to the sphere of the self should actually be one of the theses that we should abstain ourselves from positing. Thanks to this way of thinking about the epoché, Patockka considers the possibility of posing a new question: "What would happen if the epoché did not stop before the thesis of the own self, but was understood as completely universal?" 46 If epoché becomes completely universal now, it can open the way for 'appearance itself' to make its appearance, without the obstacles of taking it as being originated from the self. In fact, "maybe the immediacy of the donation of the self is not a prejudice and the experience of one's own self, just as the experience of external things, has its a priori,

41 Oded Balaban, "Epoché: Meaning, Object, and Existence in Husserl's Phenomenology," in Phenomenology WorldWide: Foundations - Expanding Dynamics — Life-Engagements. A Guide for Research and Study, ed. A. Ales Bello et al. (Dordrecht: Springer Netherlands, 2002), 111, https://doi.org/10.1007/978-94-007-0473-2_10.

42 Patočka, El movimiento de la existencia humana, 113.

43 Dušan Hruška, "Patočka and English Sensualism and Its Place in Modern Philosophy," Folia Philosophica 37, no. 0 (July 4, 2016): 28, http://www.journals.us.edu.pl/index.php/FOLIA/article/view/4732.

44 Patočka, El movimiento de la existencia humana, 129.

45 Ibid., 244.

46 Ibid., 247. 
an a priori that allows the appearance of the self." ${ }^{77}$ So, if we make epoché universal, we gain two things at once: freeing 'appearances as such' from the chains of the self and, by doing so, revealing the authentic essence of this previously misunderstood self. If we want to unfold this a priori, which is a condition for the possibility of the subjective as well as the objective, then we must universalize epoché in such a way that "it is a phenomenology void of reduction, but not without the epoché." 48 In other words, it is an a-subjective phenomenology.

This renouncement of reduction now allows us to open the phenomenological field as such, as an autonomous a priori, to whom objects and subjects appear on the same grounds: "We arrive in this way to the conditions of possibility of the appearance of what already appears; we do not remain quiet before what appears, but we allow appearance to make its appearance." ${ }^{49}$ This phenomenological field is no longer a mere stream of experiences, but a world-background, a vast horizon of meaning that only manifests, shows and bring things to presence:

A universal structure of appearance that is not reducible to what appears, in its singular being, is what we call world, which we have the right to name, since it is found in the epoché. However, it is neither negated nor doubted by the epoché, but brought into the light, and out of anonymity, by it. ${ }^{50}$

Thanks to an epoché void of reduction, appearances as such can be unfolded, showing itself as a proto-horizon of the world "in an infinity that cannot be updated. Perception does not flow in a sequence of more and more perceptual donations, but, from the beginning, it rests on a totality that is present even when is not being perceived." 51 In other words, a particular actualization of that horizon of totality does not account, on its own, for the fact that there is something. This, however, is already manifested by the fact that "the universal totality of what appears, which Patočka sometimes calls 'unapparent immensity,' belongs to the own structure of appearance, which means that every appearance is necessarily a co-appearance of that totality." 52 Every particular appearance presupposes this infinite world background as the condition of its possibility in such a way that one must conclude that this world is neither objective nor subjective, but a-subjective.

This way of conceiving the world allows Patocka to formulate an original conception of the subject. Patočka points to Descartes as the discoverer of the cogito, which is the subject revealed to itself by means of its own acts, through its existence. ${ }^{53}$ Descartes

47 Ibid.

48 Ibid., 249.

49 Ibid., 247.

50 Ibid., 248.

51 Ibid., 29.

52 Barbaras, Introducción a una fenomenología de la vida, 139

53 Jan Patočka, "The Natural World and Phenomenology," in Jan Patočka: Philosophy and Selected Writings (Chicago: University of Chicago Press, 1989), 247. 
attempts to add a thing-like essence (a thing that acts, thinks, and wants), ${ }^{54}$ in such a way that constitutes a special thing between other things that lack a self or ego. This introspectionalist ${ }^{55}$ way of conceiving the object motivates him to consider the subject as something internal, a closed-in-itself ego to which external objects oppose is inherited by Brentano, ${ }^{56}$ and, finally, by Husserl. Instead of this ego, Patočka will emphasize the cogito:

Without a doubt, the 'ego' as 'ego cogito' is proven to be immediately true. But this certainty lacks any content, except for this: it is that which appears that makes its appearance. The phenomenological field appears before this ego. ${ }^{57}$

This does not mean, however, that the cogito is the foundational entity of appearance, because as we have already said, appearance cannot be reduced to any entity. What Patocka is trying to say is that the subject acts only as an organizational center ${ }^{58}$ of this protohorizon of world. The subject is, in some way, the indexical of appearance-the 'here' of appearance. ${ }^{59}$ It indicates the direction of the appearance, but appearance always ontologically precedes the subject and presents itself before him, not through him:

Showing itself in him is no human doing: man neither produces nor shows its own being (its own 'light') or its own transparency, the interest for it or its own comprehension. In one's own being, being in general is already in action. ${ }^{60}$

Now, the essential features of the subject become available through phenomenological description. By means of this, we discover that the subject is an entity in the world whose fundamental ontological feature is that it "cares for its being and exists through time and in movement. This points even beyond the sphere of the self." 61 This entity lives within the possibilities of appearance and clings to them in its existence, in such a way that its being is explained by the phenomenical field, but not the other way around. ${ }^{62}$

Thanks to this conception of the subject and appearance, now Patocka can replace the Husserlian account of perception with his own corrections. In Patočka’s account, it is not the case that different perspectives appear and then are unified by an act of

\footnotetext{
54 René Descartes, Meditations on First Philosophy: With Selections from the Objections and Replies (OUP Oxford, 2008), 20.

55 Ibid., 97-98.

56 Dermot Moran, “The Inaugural Address: Brentano's Thesis," Proceedings of the Aristotelian Society, Supplementary Volumes 70 (1996): 2.

57 Patočka, El movimiento de la existencia humana, 129.

58 Ibid., 248.

59 Indexicals are terms that have a demonstrative function, namely, they indicate direction, place, position, etc, relative to a context or point of reference. Paradigmatic cases are "here" and "now". David Kaplan, "Demonstratives," in Themes From Kaplan, ed. Joseph Almog, John Perry, and Howard Wettstein (Oxford: Oxford University Press, 1989), 490.

60 Patočka, El movimiento de la existencia humana, 110.

61 Ibid., 111.

62 Barbaras, Introducción a una fenomenología de la vida, 157.
} 
consciousness. What is actually the case is that before me appear characteristics that "I attribute to the thing itself as its own notes and others that, although they are also there, they are not there as belonging to the thing, but, in some way, as helping the thing appear." 63 Some of the data exist as a property of the thing and belongs, and the rest of the data lack reference to that thing, which is not a property of the thing itself. This means that two types of data, which are equally objective, appear to me, at least in the sense that they are different to me. However, some of it appears with confusing traits, or lacks reference to its object. Characters that appear as belonging to a thing are thing-like traits, and the ones that lack reference to its object are nonthing-like traits. Thing-like and non-thing-like traits are just as objective, and for non-thing-like characters to become thing-like characters, an act of the subject is not necessary. Patočka compares this to the image of awakening from a dream, in which even "before what is being lived shows contours of things to me, sensations overwhelm me as I am passively taken by them. Does not something very different to things appear there; namely, a chaos, a fog, but all of that in an objective way?" 64

Finally, the noesis/noema scheme is also corrected. As we saw before, this scheme implies putting beforehand an empty signification (noesis) that needs to be corresponded by an intuition (noema). The mistake here is to consider this empty signification as an act of the subject, instead of as a structure of a-subjective appearance. What is actually the case is that there is a universal structure of emptiness/fulfillment that is not limited only to perception, and is not an act of any subject, but always operates every time a negative meaning is asking to be completed: "it can also happen that any object, existent thing, or thing-like process fails to appear." ${ }^{65}$

\section{Conclusion}

I have demonstrated that Patočka's critique (and many of the subjectivist accusations made towards Husserl) can be held, since they reveal many presuppositions that operate in the background of Husserlian theories of appearance. The fundamental conclusion from this critique is that the epoche does not imply reduction. Thus, we can envision an a-subjective phenomenology that reveals the independence of a world-horizon without restarting the natural attitude towards the world.

Nonetheless, this correction to Husserl's project is not a mere disregarding, but is, rather, a correction that keeps and shows the true aspect of many of Husserl's theories. In a certain way, we can see Patočka as an inheritor who critically continues the task started by the first phenomenologist. Patočka expresses this intent, saying that:

63 Patočka, El movimiento de la existencia humana, 126.

64 Ibid.

65 Ibid., 132. 
Maybe the last will of the creator of phenomenology should be considered: effecting the catharsis of the phenomenological and giving back to phenomenology its original sense of an investigation of appearances-assuch. ${ }^{66}$

\section{BIBLIOGRAPHY}

Balaban, Oded. "Epoché: Meaning, Object, and Existence in Husserl's phenomenology.” In Phenomenology World-Wide: Foundations - Expanding Dynamics - Life-Engagements. A Guide for Research and Study, edited by A. Ales Bello, M. Antonelli, G. Backhaus, O. Balaban, G. Baptist, J. Bengtsson, J. Benoist, et al., 103-14. Dordrecht: Springer Netherlands, 2002. https://doi. org/10.1007/978-94-007-0473-2_10.

Barbaras, Renaud. Introducción a una fenomenología de la vida: intencionalidad y deseo. Encuentro, 2013.

Biemel, Walter. "Las Fases Decisivas En El Desarrollo de La Filosofía de Husserl." In Husserl. Tercer Coloquio Filosófico de Royaumont, 35-57. Buenos Aires: Paidós, 1968.

Crowell, Steven. "Phenomenological Immanence, Normativity, and Semantic Externalism." Synthese 160, no. 3 (2008): 335-54.

Descartes, René. Meditations on First Philosophy: With Selections from the Objections and Replies. OUP Oxford, 2008.

Dostal, Robert J. "Subjectivism, Philosophical Reflection and the Husserlian Phenomenological Account of Time.” In Phenomenology on Kant, German Idealism, Hermeneutics and Logic: Philosophical Essays in Honor of Thomas M. Seebohm, edited by O. K. Wiegand, R. J. Dostal, L. Embree, J. Kockelmans, and J. N. Mohanty, 53-65. Dordrecht: Springer Netherlands, 2000. https://doi. org/10.1007/978-94-015-9446-2_4.

Hanna, Robert. "Husserl's Arguments against Logical Psychologism.” Edmund Husserl: Logische Untersuchungen, 2008, 27-42.

Himanka, Juha. "Husserl's Two Truths: Adequate and Apodictic Evidence." Phänomenologische Forschungen, 2005, 93-112.

Hruška, Dušan. "Patočka and English Sensualism and Its Place in Modern Philosophy." Folia Philosophica 37, no. 0 (July 4, 2016). http://www.journals. us.edu.pl/index.php/FOLIA/article/view/4732.

Husserl, Edmund. Ideas: General Introduction to Pure Phenomenology. Routledge, 2014.

66 Ibid., 109. 
—. Logical Investigations. Routledge, 2013.

Ierna, Carlo. "Making the Humanities Scientific: Brentano's Project of Philosophy as Science." In The Making of the Humanities. Volume III: The Making of the Modern Humanities, edited by Rens Bod, Jaap Maat, and Thijs Weststeijn, 543-554. Amsterdam University Press, 2014.

Kant, Immanuel. Critique of Pure Reason. Edited by Paul Guyer and Allen W. Wood. Cambridge: Cambridge University Press, 1999.

Kaplan, David. "Demonstratives." In Themes From Kaplan, edited by Joseph Almog, John Perry, and Howard Wettstein, 481-563. Oxford: Oxford University Press, 1989.

Moran, Dermot. "Immanence, Self-Experience, and Transcendence in Edmund Husserl, Edith Stein, and Karl Jaspers." American Catholic Philosophical Quarterly, May 1, 2008. https://doi.org/10.5840/acpq20088224.

—. "The Inaugural Address: Brentano's Thesis." Proceedings of the Aristotelian Society, Supplementary Volumes 70 (1996): 1-27.

Öktem, Ülker. "Husserl's Evidence Problem." Indo-Pacific Journal of Phenomenology 9 , no. 1 (May 1, 2009): 1-14. https://doi.org/10.1080/20797222.2009.11433986.

Paredes, María. "Percepción y Atención. Una Aproximación Fenomenológica." Azafea: Revista de Filosofía; Vol. 14 (2012), 2014. http://revistas.usal.es/index. $\mathrm{php/0213-3563/article/view/11680.}$

Patočka, Jan. El Movimiento de la existencia humana. Encuentro, 2004.

—_. "The Natural World and Phenomenology." In Jan Patočka: Philosophy and Selected Writings, 239-74. Chicago: University of Chicago Press, 1989.

Schrader, George Alfred. "Philosophy and Reflection: Beyond Phenomenology." The Review of Metaphysics 15, no. 1 (1961): 81-107.

Smith, A. David. "Husserl and Externalism." Synthese 160, no. 3 (2008): 313-33.

Smith, David Woodruff. "Phenomenology." In The Stanford Encyclopedia of Philosophy, edited by Edward N. Zalta, Summer 2018. Metaphysics Research Lab, Stanford University, 2018. https://plato.stanford.edu/archives/sum2018/entries/ phenomenology/.

Tassone, Biagio G. "The Relevance of Husserl's Phenomenological Exploration of Interiority to Contemporary Epistemology." Palgrave Communications 3 (July 11, 2017): 17066.

Whitehead, Patrick. "Phenomenology Without Correlationism: Husserl's Hyletic Material.” Indo-Pacific Journal of Phenomenology 15, no. 2 (October 26, 2015): 1-12. https://doi.org/10.1080/20797222.2015.1101830. 
Williford, Kenneth. "Husserl's Hyletic Data and Phenomenal Consciousness."

Phenomenology and the Cognitive Sciences 12, no. 3 (September 1, 2013): 501-19. https://doi.org/10.1007/s11097-013-9297-z.

Zahavi, Dan. Husserl's Phenomenology. Stanford University Press, 2003.

Zuidervaart, Lambert. "Synthetic Evidence and Objective Identity: The Contemporary Significance of Early Husserl's Conception of Truth." European Journal of Philosophy 26, no. 1 (2018): 122-44. https://doi.org/10.1111/ ejop.12192. 